\title{
Analysis of the top companies' performances in the different sustainability rankings
}

\author{
Marius Constantin Profiroiu ${ }^{1}$,Iulian Gole ${ }^{1, *}$, and Carmen Valentina Rădulescu ${ }^{1}$ \\ ${ }^{1}$ Bucharest University of Economic Studies, 6 Piata Romana, Bucharest, Romania
}

\begin{abstract}
Research background: Since the end of COP 21 in Paris 2015 and even before, there is a huge interest for big companies to see their names at the top of the different ranking, as sustainability leaders. It is not only a matter of pride but also a business interest to promote sustainability values. The countries engage themselves to reduce global warming but this can only be done by reducing greenhouse gas emissions. Multinationals companies are in the position to bring a huge contribution to this objective. In this paper, we will try to evaluate different rankings done by various organisations, different companies that are in top positions in order to understand the real advancement.

Purpose of the article: We want to see what is similar but also what differentiates one company from another. We will also analyse what the main key performance indicators are, used in to assess the evolution over time and how the companies are communicating their progress. We want to demonstrate if there is any common ground among different rankings or if there are huge differences in terms of results.

Methods: Using descriptive and comparative analysis we demonstrate that different companies are entitled as champions of different rankings, using different metrics.

Findings \& Value added: In a global world, we can see that there is an important commercial interest of companies to appear in front of clients and investors as upholders of sustainability. Showing off a label of sustainability leader can help in doing business but it is not always corresponding with reality.
\end{abstract}

Keywords: environment protection; sustainability; multinational companies; survey

JEL Classification: $C 43 ; O 44, Q 54 ; Q 56 ; B 16$

\footnotetext{
*Corresponding author: iuliangole@yahoo.com
} 


\section{Introduction and research background}

Many researchers proved during recent years that the companies and organizations (national and international) achieve better results when they construct their business plans having in mind the environmental issue (Purvis et al., 2019), a higher quality of life for their employees and for the clients (Whelan and Fink, 2016), the care for global resources - generally speaking, the concern for all stakeholders (Bodislav et al., 2020).

Compared to national firms, international companies are obliged to deal with many challenges (Bran et al., 2020). Most important is to know how to manage multicultural project teams; at the same time, they have to support collaboration by benefitting from using global technologies (Lasrado, 2018) - luckily, we live in a period when technological advancement is developing faster than ever (Profiroiu et al., 2020). The latest technological upraise in artificial intelligence, robotics, and biotechnology, have revealed new possibilities for sustainable development (UNCTAD, 2021). We cannot think of achieving sustainable development without building a strong basement of responsibility and good practices (Dima et al., 2020). Nevertheless, successful companies will always need to create and implement business plans and strategies (Burlacu et al., 2019), and those who will succeed will not only generate new sources of innovation, but they will have their employees excited and stakeholders loyal (Crowther et al., 2018). The objective of this research is to understand how the international companies are positioned in different ranking, to understand why we have such differences from one market research to another, and which the best actors in this area are.

As a starting point, we decided to look at a survey conducted by GlobeScanSustainAbility Leaders Survey (Globescan, 2019). We consider that the results of this survey are worthy to be taken into consideration, not only because it is about one of the most prestigious research institutions but mainly because around 800 experts were interviewed, people coming from the business environment, government, NGOs as well as academia, from 78 countries on different continents. This paper is important because we can see what the perception of experts is, on companies that are publicly declared having as main objective the integration of sustainable development into their business strategy. In order to compare with other rankings is important to see how top international companies are perceived by specialists, and what kinds of indicators are analyzed (Radulescu et al., 2020).

The next phase of our paper is to look at other rankings, realized by different institutions, and compare the results between them. Most interesting is to see why they are so different and what can be done to have a clear and honest classification.

\section{Methods}

Concerning the methodology of building the questionnaire which stays at the base of GlobeScan-SustainAbility Leaders Survey, the whole analysis consists in the assessment of perception that different specialists have on who are the performing companies from the sustainability perspective $5 \%$ coming from governmental sectors, $16 \%$ from academic and research institutes, $16 \%$ from NGOs, $21 \%$ from media, $36 \%$ from corporate and the rest of $6 \%$ from other sectors), working in the field of sustainability and sustainable development, people with a recognized level of expertise accumulated over several years $(67 \%$ having at least 10 years of experience, 
$23 \%$ have worked between 5 and 10 years and $10 \%$ of the respondents being involved in the field of sustainability between 3 and 4 years), who come from different areas of activity but also different geographical areas (9\% from Africa and Middle East, 14\% from Latin America, 21\% from Asia-Pacific, 25\% from North America and 31\% from Europe). That is why we consider that this questionnaire is one of the most representatives in the field and can be used successfully as a starting point for our further analysis.

The Global 100 is a different ranking, realized by Canadian research firm Corporate Knights since 2005 (Todd, 2021), which creates a deeper analysis regarding the companies that obtained important positive results by shifting their business model, accepting sustainable practices as rules and as not exceptions. Since 2005 the results were published during the World Economic Forum annual meeting in Davos, Switzerland. The Global 100 takes into consideration international corporations with revenue over at least $\$ 1$ billion and its exploration is based on key metrics of sustainability - from the carbon footprint, water consumption but also and gender diversity.

Calvert Research \& Management created "The 100 Most Sustainable Companies Right Now". In order to rank the companies, they look first market value of the largest publicly traded and then they asses according to five key criteria: shareholders, employees, customers, community, and the planet. 230 ESG indicators were taken into consideration (among them workplace diversity, data security, GHG emissions) and we will see the results in the next chapter.

We consider will be interesting to see the differences between these three analyses and even more appealing to understand why the results are so different.

\section{Results and discussion}

\subsection{Perception of large corporations, leaders in promoting the values of sustainability and sustainable development - GlobeScan-SustainAbility Leaders Survey}

The survey measures many characteristics and presents interesting answers. At the question of which specific companies you consider are leaders in integrating sustainability into their business strategy, respondents had to choose a maximum of 3 names. As we can see there is a certain continuity of results, over the years, absolutely natural since it is impossible to make spectacular qualitative steps from one year to another. In any case, there is also a certain evolution; depending on different indicators (Angheluta et al., 2019). In the next picture, we can see what the most appreciated 10 multinationals performances are.

Unilever, Patagonia, and IKEA are in the top three positions in the top ten. A large majority of these leading companies had theirs headquarter in Europe. The only company coming from an emerging economy that has a good result on this assessment is the Brazilian cosmetics multinational - Nature. It is worth mentioning that BASF came back in the top ten after an exit off the list of leaders in 2018. It is also interesting to observe what the evolution of top 10 companies is during the last 10 years; as we said there is a certain up and dawn but Unilever remains undoubtedly the best performer during the last decade since sustainable development has been accepted as one of the most important issues of our time. 


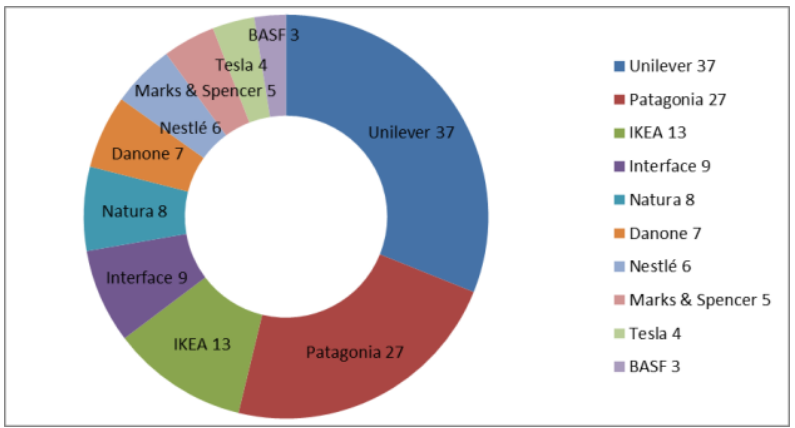

Figure 1. Ranking of the top 10 companies, perceived to be leaders in sustainable development.

Source: Own representation from the data obtained in the GlobeScan report.

When we look at what has happened in the last 10 years with the perception of these companies we will see that there are interesting developments. The extent to which the experts appreciate Patagonia as a leader in terms of sustainability is on a steady growth path during the last 10 years. The advancement of Unilever became to diminish, for the first time in the last decade. The decrease can be explained by the change of CEO in 2019, this survey measures the perception of experts and not necessarily specific performance indicators (as water consumption, GHG emission, waste, etc ).

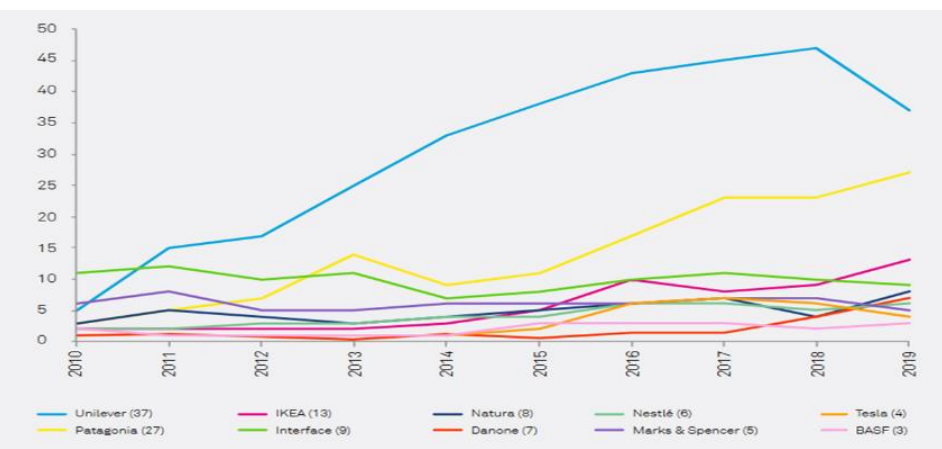

Figure 2. The evolution of the ranking of specialists' perception on the leading companies of sustainability, in the last 10 years

Source: Data from the GlobeScan report.

The performances of IKEA, Natura, and Danone were also well appreciated by the specialists. One of the most stable multinationals, in the eyes of experts, from the sustainability point of view, remains Interface - during the last decade this company was always on top four.

There are very big differences, at the geographic level, concerning the specialists' perception (Bran et al., 2018). The assessment went more into detail and tried to see, in the expert's perception, what are the best companies which operate in their home region (Alpopi et al., 2018). The results are interesting because a variety of enterprise 
names came up which means that many of them gained visibility due to the sustainability approach of business.

As we can see in the next picture, the majority of specialists coming from Latin America and North America choose Nature and Patagonia as being in the first position.

Logically, those who are considered as being regional leaders can be seen at a global scale in the top 10 as well. As always, some exceptions may happen. Even though Toyota is perceived as a leader in Asia and Aramex in Africa, still they don't appear in the global top 10 list. This is because although at the regional level the efforts of these companies are recognized by the specialists, still at the global level other companies are considered to do greater work. Multinationals operating in Europe, North America, and South America are perceived as being more active and consequently are more appreciated.

We also see that some companies are more recognized in their geographical areas than globally (Walmart, Apple, Microsoft), which is natural.

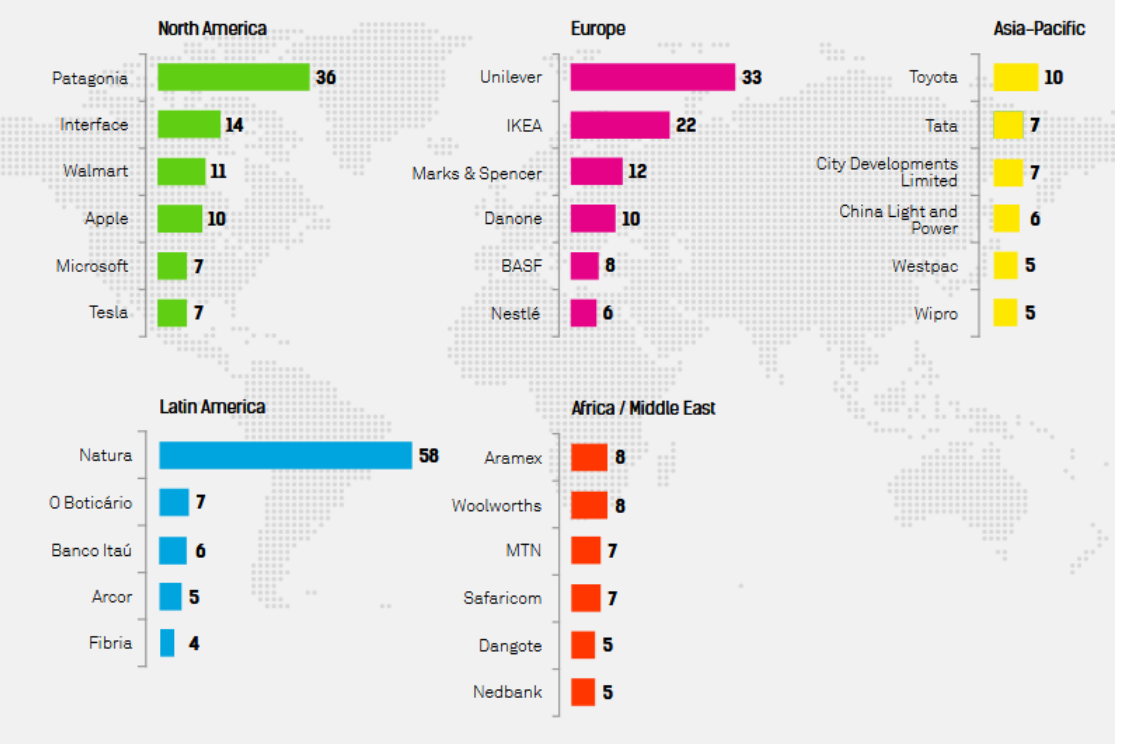

Figure 3. Perception of corporations by geographical area

Source: Data from the GlobeScan report

It is also interesting to see what the values are, on which experts have constructed their assessments about the activities of those companies, how the specialists defined the corporate leadership. In the chart below we see that integrated values of sustainability and maintaining the sustainable development as part of the core business model are seen as key factors of leadership in sustainability. 


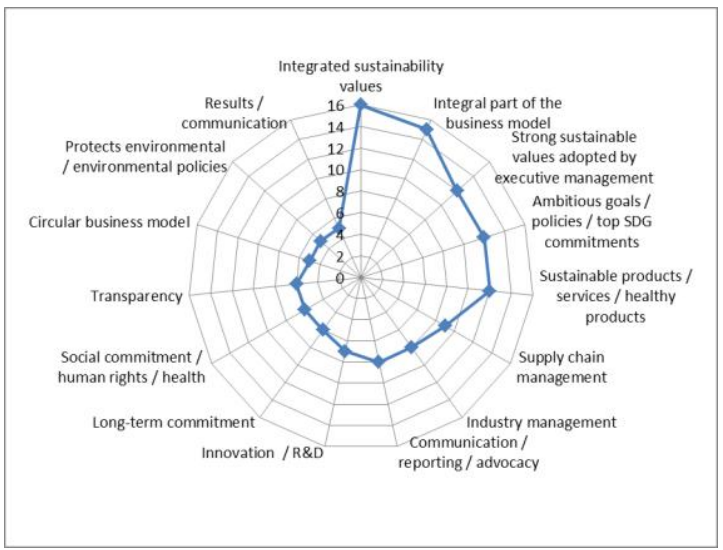

Figure 4. The values of corporate governance

Source: Own representation from the data obtained in the GlobeScan report.

As can be seen from the chart above, experts believe that integrating sustainability values into the DNA of the business model is the most important value that corporate management manages to develop. Offering sustainable products and services, a supply chain that respects the principles of sustainability, a clear direction of future development coming from the management of the branches, in different industries, is also perceived as very important. We will try to compare these results with other data from different analyses.

\subsection{Global 100}

We will continue our research by evaluating another research realized by Corporate Knights. As we said this ranking takes into consideration only the companies with revenues of at least 1 billion. Among some of the traditional key performance indicators as carbon footprint, water consumption, energy, waste, etc., this evaluation take into account other types of indexes as taxes paid, clean revenues, clean investment, CEO-average worker pay score, retirement contribution, fatalities per employee, employee turnover, non-male on board, racial diversity among boards, etc. This type of assessment is different from the first one because it is based on specific indicators and not only the feeling of experts even though the results should be at least similar since the perception should be based on facts. In the next table we have listed the first 10 performers (Corporate Knights, 2021).

Table 1. Top 10 companies in Global $100-2020 / 2021$

\begin{tabular}{|c|c|c|c|}
\hline $\begin{array}{c}\text { Rank } \\
2021\end{array}$ & $\begin{array}{c}\text { Rank } \\
2020\end{array}$ & Company name & Peer Group (CKIG) \\
\hline 1 & 29 & Schneider Electric SE & Industrial Conglomerates \\
\hline 2 & 1 & Orsted A/S & Power Generation \\
\hline 3 & 9 & Banco do Brasil SA & Banks and Investment Services \\
\hline
\end{tabular}




\begin{tabular}{|c|c|c|c|}
\hline 4 & 3 & Neste Oyj & Oil \& Gas \\
\hline 5 & 57 & Stantec Inc & Consulting and Professional Services \\
\hline 6 & 22 & McCormick \& Company Inc & $\begin{array}{c}\text { Packaged and Processed Food and } \\
\text { Ingredients }\end{array}$ \\
\hline 7 & 23 & Kering SA & Clothing and Accessory Retail \\
\hline 8 & 18 & Metso Outotec & Construction \& Engineering Services \\
\hline 9 & 16 & $\begin{array}{c}\text { American Water Works } \\
\text { Company Inc }\end{array}$ & Water Utilities \\
\hline
\end{tabular}

Source: data from "2021 Global 100 ranking".

We can also see a certain evolution during the last two years. Almost $50 \%$ of the companies from Global 100 list are based in Europe, 29 in the U.S. while 18 in Asia.

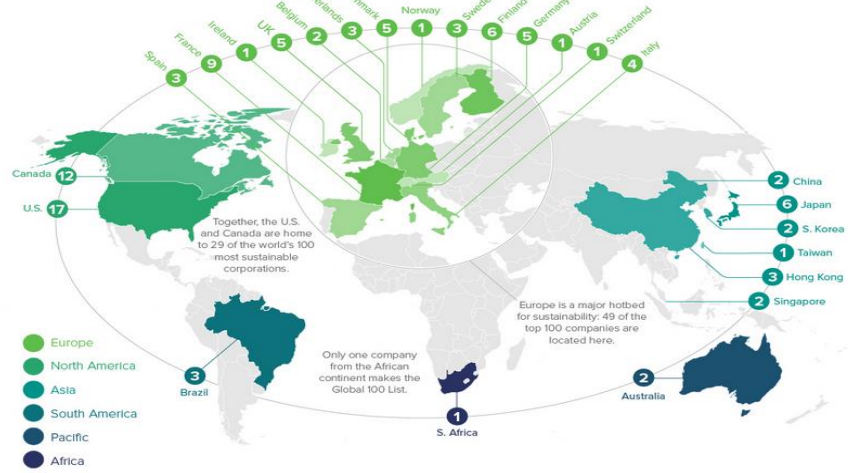

Figure 5. Top companies per region in 2020.

Source: Ghosh, 2020.

The champion of 2020 was Orsted, a Danish energy provider company. It is the first electricity enterprise that has been awarded the number 1 distinction. It is even more remarkable since the company went up 69 positions comparing with 2018. This recognition was possible because they reinvented their business model, over the last decade, from coal intensive to almost a pure renewable power provider. The company divested from the fossil fuels sector and reinvest massively in wind power, which allowed toe Orsted to reduce its carbon emissions by $83 \%$. Almost 13 million people are using clean energy provided by Orsted and the aim of the company is to reach 50 million by 2050 .

The winner of 2021 is Schneider, an industrial conglomerate that provides provide energy and automation digital solutions. Their main products are "building automation, home automation, switches and sockets, industrial safety systems, industrial control systems, electric power distribution, electrical grid automation, Smart Grid, critical power \& cooling for datacenters" (Schneider, 2021). By investing in digitalization and electrification, the company accepted the climate change 
challenge 15 years ago. In 2020 the company reaches $80 \%$ renewable energy, $8.4 \%$ $\mathrm{CO} 2$ efficiency in transportation, 134 million metric tons of $\mathrm{CO} 2$ saved. All these achievements allowed Schneider to climb on number one position in 2021 from 29 in 2020. Without any doubt, this is remarkable progress.

As we can see none of the first 10 companies perceived as having an outstanding performance by the experts working in environmental fields, in the GlobalScan report, are on the list of Global 100. The only three companies that appear in Corporate Knights ranking are Unilever on 79 positions (down from 46 in 2020), Natura on 42, and Tesla on 97.

\subsection{The 1000 Most Sustainable Companies}

In order to have another perspective, we will have a look at a third ranking, realized by Calvert Research \& Management. They took into consideration the first 1000 largest publicly traded companies by market value. The next criteria are to consider the top companies in the ESG area (environment, sustainability, governance) and these are the results:

Table 2. Ranking of 100 most sustainable companies

\begin{tabular}{|c|c|c|c|c|}
\hline 2021 Rank & 2020 Rank & Company & 2020 Total return & Recent price \\
\hline 1 & 5 & Best Buy & $18 \%$ & 117,9 USD \\
\hline 2 & 1 & Agilent Techologies & 38,3 & 123,41 \\
\hline 3 & 17 & Ecolab & 12,5 & 217,05 \\
\hline 4 & 10 & Autodesk & 63,3 & 302,81 \\
\hline 5 & 3 & Voya Financial & $-3,5$ & 58,38 \\
\hline 6 & 4 & Tiffany & 0,2 & 131,46 \\
\hline 7 & 46 & Robert Half & 0,5 & 72,1 \\
\hline 8 & 21 & V.F. Corp & $-11,6$ & 81,7 \\
\hline 9 & 30 & Verizon & $-1,3$ & 55,05 \\
\hline 10 & 15 & ON Semiconductor & 33,3 & 39,81 \\
\hline
\end{tabular}

Source: Calvert Research \& Management (Norton, 2021).

If we look into details we can see that none of the companies from GlobeScan report can be found in this ranking. Among the leaders of the Global 100 report, only American Water Works Company Inc. is ranked in $15^{\text {th }}$ position and McCormick on $56^{\text {th }}$, the rest of the top 10 doesn't exist.

\section{Conclusions}

It is obvious that sustainability became a major preoccupation for the top management in recent years. More and more, international organizations (the U.N. or W.E.F.) are pushing transnational corporations to present how they take care of their stakeholders and for the planet. Transparency is a must to be successful in business (Negescu Oancea, et al., 2020). How they can express their performances is a sensitive issue 
because not everyone is adopting the same set of rules or indicators (Profiroiu et al., 2020).

We have to admit there is a huge difference among these rankings. How can be that possible? The answer is because in the first assessment (Globe Scan) what is measured is the perception of the respondents while in the second there are a variety of specific indicators - not only the classical GHG emission, waste, water consumption (which probably the respondents of first assessment had in mind when they ranked the companies) but also clean investments, taxes paid, lost-time injury rate, fatalities per employee, non-male senior executives, racial diversity, etc. In the third, what matters more is the shareholders, employees, customers, community, and nature, but this is coming at last. In order to measure that, they look at workplace diversity, data security, and GHG emissions and they created a weighted average For example, the fact a company tried to protect the jobs during the Covid-19 pandemic weighted a lot.

It is clear that when we calculate a weighted average of all these indicators, certainly the results are those presented in each report, there is no space for mistake taking into consideration the performance of computing programs. Still the results are so different because each ranking measures a different thing and gives a different weight to specific indicators. That is why we have situations where a company is ranked on the first position in one assessment and another hierarchy does not appear at all.

To increase the transparency and credibility of the companies and of those who realized these rankings would be much better to use the same standards. It would be easier even for companies to use the same key performance indicators in the communication regarding their contribution to sustainability. Otherwise, it remains only a simple exercise of a showoff, more or less credible.

\section{References}

1. Alpopi, C., Burlacu, S., \& Ioviţu, M.(2018). Procesul de globalizare şi politicile ecologice. Competitivitatea şi Inovarea în Economia Cunoaşterii, 2, 317-324.

2. Angheluta, S. P., Burlacu, S., Diaconu, A., \& Curea, C. S. (2019). The Energy from Renewable Sources in the European Union: Achieving the Goals. European Journal of Sustainable Development, 8(5), 57.

3. Bodislav, D.A., Radulescu, C.V., Bran, F., \& Burlacu, S. (2020). Public Policy in the Areas of Environment and Energy. 6th BASIQ International Conference on New Trends in Sustainable Business and Consumption. Messina, Italy, (pp. 228235).

4. Bran, F., Rădulescu, C. V., Bodislav, D. A., \& Burlacu, S. (2020). Environmental risks in the context of globalization. Economic Convergence in European Union, 350 .

5. Bran, F., Burlacu, S., \& Alpopi, C. (2018). Urban Transport of Passengers in Large Urban Agglomerations and Sustainable Development. Experience of Bucharest Municipality in Romania. European Journal of Sustainable Development, 7(3), 265-273.

6. Burlacu, S., Alpopi, C., Mitrită, M., \& Popescu, M. L. (2019). Sustainable eGovernance and Human Resource Development. European. Journal of Sustainable Development, 8(5), 16. 
7. Dima, C., Burlacu, S., \& Buzoianu, O. A. C. (2020). Strategic Options for the Development of Ecotourism in the Danube Delta in the Context of Globalization. SHS Web of Conferences, 74, (p. 4005).

8. Crowther, D., Seifi, S. \& Wond, T. (2018). Responsibility and Governance: The Twin Pillars of Sustainability (Approaches to Global Sustainability. Springer.

9. Ghosh, I. (2020). Mapped: Where Are the World's Most Sustainable Companies? Retriewed from: https://www.visualcapitalist.com/most-sustainable-companies/

10. Globescan (2019). The 2019 GlobeScan SustainAbility Leaders Survey Report. Retrieved from https:/globescan.com/2019-sustainability-leaders-report/

11. Global 100 ranking (2021). Corporate Knights. Retrieved from https://www.corporateknights.com/reports/2021-global-100/2021-global-100ranking-16115328/

12. Lasrado, F. (2018). Achieving Organizational Excellence: A Quality Management Program for Culturally Diverse Organizations. Springer.

13. Negescu, M. D., Burlacu, S., Mitriţă, M., \& Buzoianu, O. C. A. (2020). Managerial Analysis of Factoring at the International Level Challenges of the Contemporary Society. Proceedings; Cluj-Napoca, 13(1), 99-102.

14. Norton, L. (2021). Here are the most 100 most sustainable companies right now. Retrieved from https://webreprints.djreprints.com/57969.html

15. Profiroiu, C. M., Bodislav, D. A., Burlacu, S., \& Rădulescu, C. V. (2020). Challenges of Sustainable Urban Development in the Context of Population Growth. European Journal of Sustainable Development, 9(3), 51-51.

16. Profiroiu, M. C., Radulescu, C. V., Burlacu, S., \& Guţu, C. (2020). Changes and trends in the development of the world economy. Competitivitatea şi inovarea $\hat{i}$ economia cunoaşterii, (pp. 324-330).

17. Purvis, B., Mao, Y., \& Robinson, D. (2019), Three pillars of sustainability: in search of conceptual origins. Sustainability Science 14, 681-695.

18. Rădulescu, C. V., Burlacu, S., Bodislav, D. A., \& Bran, F. (2020). Entrepreneurial Education in the Context of the Imperative Development of Sustainable Business. European Journal of Sustainable Development, 9(4), 93-93.

19. Schneider Company profile (2021). Retriewed from : https://www.se.com/ww/en/

20. Todd, S. (2021). Who Are The 100 Most Sustainable Companies Of 2020? Retriewed from : https://www.forbes.com/sites/samanthatodd/2020/01/21/whoare-the-100-most-sustainable-companies-of-2020/? sh=fb93ad014a49

21. UNCTAD, 2021 TECHNOLOGY AND INNOVATION REPORT 2021. Catching technological waves. Innovation with equity. Retrieved from https://unctad.org/system/files/official-document/tir2020_en.pdf

22. Retriewed from : https:/unctad.org/system/files/officialdocument/ciimem4d20_en.pdf

23. Whelan, T., \& Fink, C. (2016). The Comprehensive Business Case for Sustainability. Harvard Business Review. 